\title{
Investigation of the effects of domestic waste on aquatic bacterial distribution in the Meric River (Edirne, Turkey)
}

\author{
Gonul Bulbul, \\ Belgin Camur-Elipek* \\ Department of Biology, \\ Faculty of Science, \\ Trakya University, 22030 Balkan \\ Yerleşkesi Edirne, Turkey
}

\begin{abstract}
The aim of this study was to investigate the effects of domestic waste on aquatic bacterial distribution in the Meric River located in the city centre of Edirne (Turkey). For this purpose, total mesophilic aerobic bacteria, total coliform, faecal coliform, and Eschericia coli bacteria were examined in the river. Also, some physicochemical features (water temperature, dissolved oxygen, $\mathrm{pH}$, conductivity, total hardness, magnesium, calcium, orthophosphate, nitrite nitrogen and nitrate nitrogen) were measured at the same time with bacterial sampling. The Spearman correlation index was used to evaluate the correlation between the bacterial distribution and environmental features. According to the results of the index, it was found that bacterial distribution related with some environmental variables, but overloading of wastewaters from settlements lead to bacterial contamination. Furthermore, bacterial and physicochemical datasets were grouped using some multivariate analysis techniques (cluster analysis, principle components, and correspondence analysis). The results grouped the sampling localities by their bacterial, including physicochemical, features.
\end{abstract}

Keywords: domestic waste, environmental features, water quality

\section{INTRODUCTION}

People take water from the hydrological circle, use it and then return it back to the circle after changing its physicochemical and bacteriological features. Rapid growth of population of the recent years, industrial developments, and agricultural activities lead to water pollution in aquatic ecosystems. The increasing demand for clean water resources requires monitoring of fresh water. Awareness of current biological and phys-

\footnotetext{
* Corresponding author. Email: belgincamur@yahoo.com; belginelipekcamur@trakya.edu.tr
}

icochemical properties of water resources is very important for ensuring their sustainable use. In recent years, coliform bacteria have been used as indicator microorganisms to determine the quality of surface waters. Their distribution can also change depending on such environmental parameters as temperature and $\mathrm{pH}$ (Lindstrom et al., 2005). Also, E. coli bacteria is known as a pollution indicator species in aquatic environments (Kenar, Altindis, 2001). Although inland waters have some microorganisms naturally, other microorganisms from soil, air, and settlements can also enter aquatic environments. Thus the inclusion of bacteria of a water resource can increase. 
The Meric River has its origin in Bulgaria, enters Turkey in the city of Edirne, and flows into the Aegean Sea from Saros Bay. The river forms the border between Greece and Turkey. Before becoming the border, the Meric River flows through the centre of Edirne. This study investigated the effects of domestic waste waters from Edirne on bacterial distribution, including the Meric River. Also, some multivariate analysis techniques were used to evaluate datasets of environmental and bacteriological findings.

\section{MATERIALS AND METHODS}

\section{The sampling area}

The city centre of Edirne is located in the European part of Turkey (Turkish Thrace). The Meric River (the Maritsa River in Bulgarian; the Evros River in Greek) enters the city from Bulgaria and passes through the city centre. The river is the border between Greece and Turkey, then it flows into the Aegean Sea after making a class A wetland in both Turkey and Greece. Five different stations on the Meric River located on Edirne city centre were chosen for this study. Sampling was done at monthly intervals during the period from December 2012 to May 2013. Station 1 was located at the spot where the river enters the city centre. Station 2 was based in a locality partly affected by people. Station 3 was positioned near the area where the wastewaters of Edirne are discharged into the river. Station 4 was located in a sparsely populated area, and station 5 was placed relatively far from the city centre compared to other stations (Fig. 1).

Sampling was made to obtain the number of total mesophilic aerobic bacteria (TMAB), total coliform bacteria (TCB), faecal coliform bacteria (FCB), and E. coli bacteria by using the membrane filtration method. For this aim, dilutions between $10^{-2}$ and $10^{-6}$ were used for bacterial incubation (Halkman, 2005). The R2A agar was used for total mesophilic aerobic bacteria (at $37 \pm 0.1^{\circ} \mathrm{C}, 24$ hours), Endo-NKS (Sartorius) agar was used for total coliform bacteria (at $37 \pm 0.1^{\circ} \mathrm{C}, 24$ hours), and mFC-NKS (Sartorius) nutrient pad systems were used for faecal coliform bacteria (at $44.5 \pm 0.1^{\circ} \mathrm{C}, 24$ hours). E. coli bacteria were identified biochemically by using the IMVIC test.

Furthermore, some environmental variables (water temperature, dissolved oxygen, $\mathrm{pH}$, conductivity, total hardness, calcium, magnesium, salinity, chloride, o- $\mathrm{PO}_{4}, \mathrm{NO}_{2}-\mathrm{N}, \mathrm{NO}_{3}-\mathrm{N}$ ) were measured during bacterial sampling. While some parameters (water temperature, dissolved oxygen, $\mathrm{pH}$, and conductivity) were measured during field studies, the others were measured in a laboratory through the application of classical chemical methods (Egemen, Sunlu, 1999).

Spearman correlation index was applied to determine the correlation between the bacteria

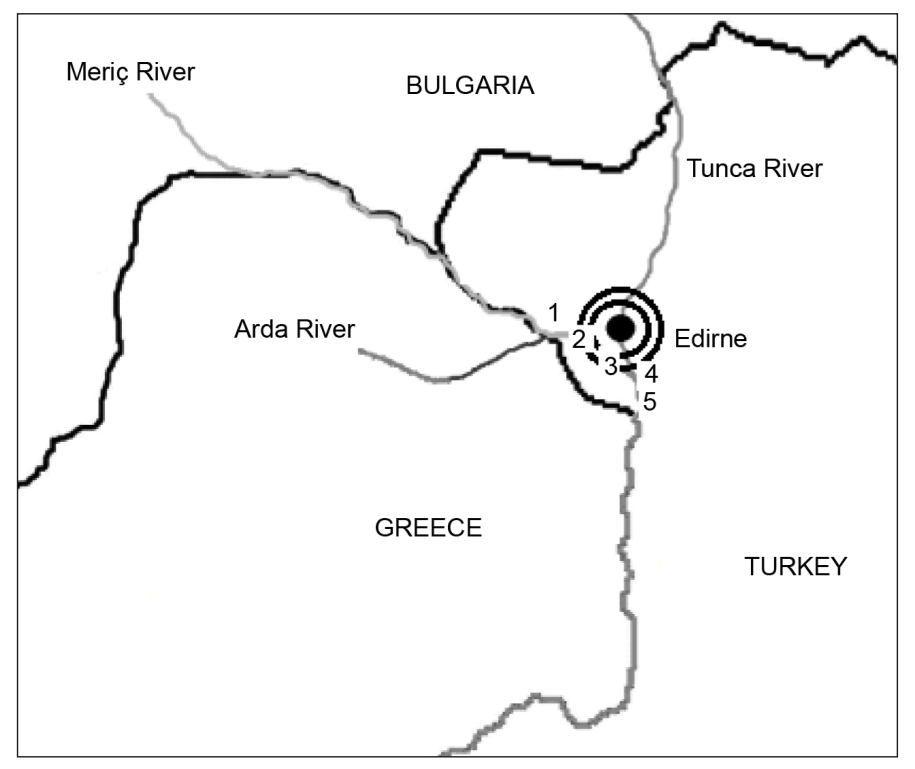

Fig. 1. Locations of the sampling stations 
and environmental features (Krebs, 1999). Also, some multivariate statistical techniques (cluster analysis, correspondence analysis, and principal component analysis) in Microsoft Office Excel 2003 and SPSS 9.0 for Windows were used to evaluate the datasets. Cluster analysis was used to evaluate similarities between the sampling stations and the results were supported by principle component analysis. Thus, the datasets of environmental parameters and bacteriological findings were grouped.

\section{RESULTS AND DISCUSSION}

Total mesophilic aerobic bacteria can occur both in aquatic environments and in land area. Total coliform bacteria, including faecal coli- forms, are common in aquatic ecosystems but the numbers should be limited.

It was determined in this study that the numbers of bacteria ranged between $8.6 \times 10^{4}$ and $1.2 \times 10^{7} \mathrm{cfu} / 100 \mathrm{~mL}$ for TMAB, between $6.0 \times 10^{3}$ and $4.8 \times 10^{6} \mathrm{cfu} / 100 \mathrm{~mL}$ for TCB, and between $3.3 \times 10^{2}$ and $3.9 \times 10^{5} \mathrm{cfu} / 100 \mathrm{~mL}$ for FCB (Fig. 2). The results found were at an expected level of bacteria in aquatic environments, because TCB includes FCB, and TMAB includes both of them.

According to the bacterial findings at the sampling stations, including TMAB, TCB, and FCB, station 3 was found to have the highest bacterial numbers (Fig. 3). The findings were supported by cluster analyses (Fig. 4). Also, the results were grouped by principle



Fig. 2. Bacteria numbers at monthly intervals

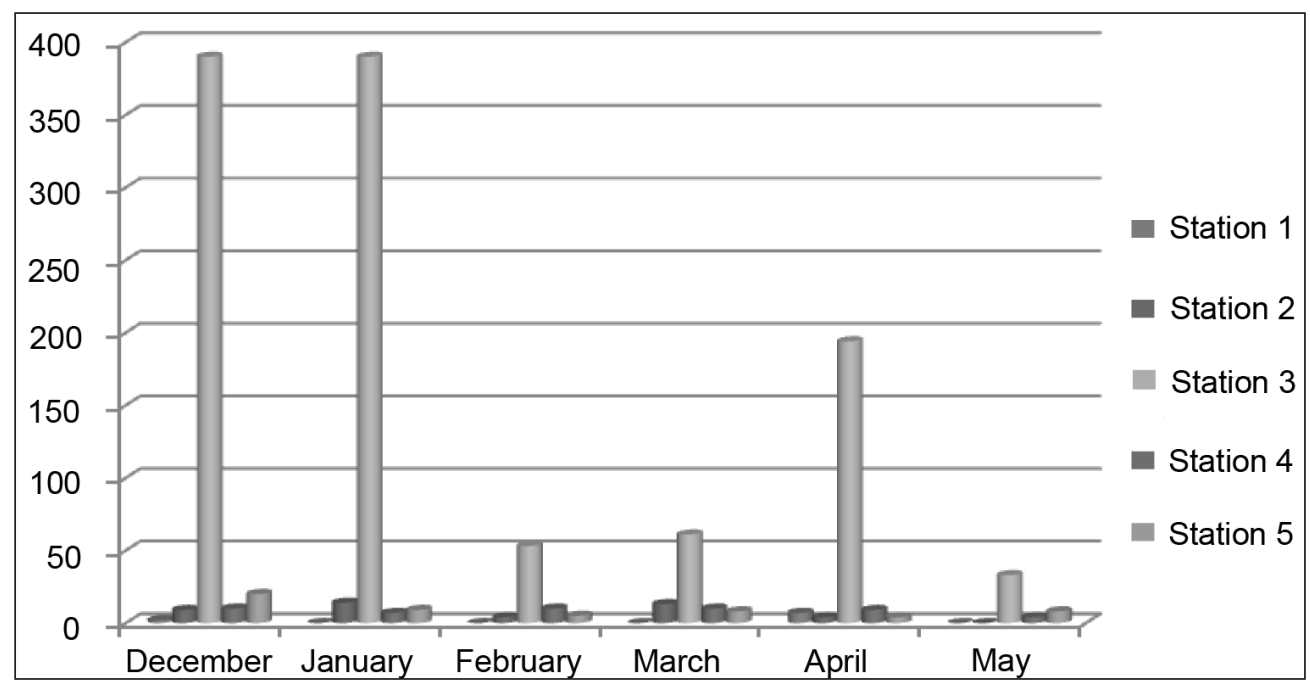

Fig. 3. Distribution of faecal coliform bacteria at the sampling stations 


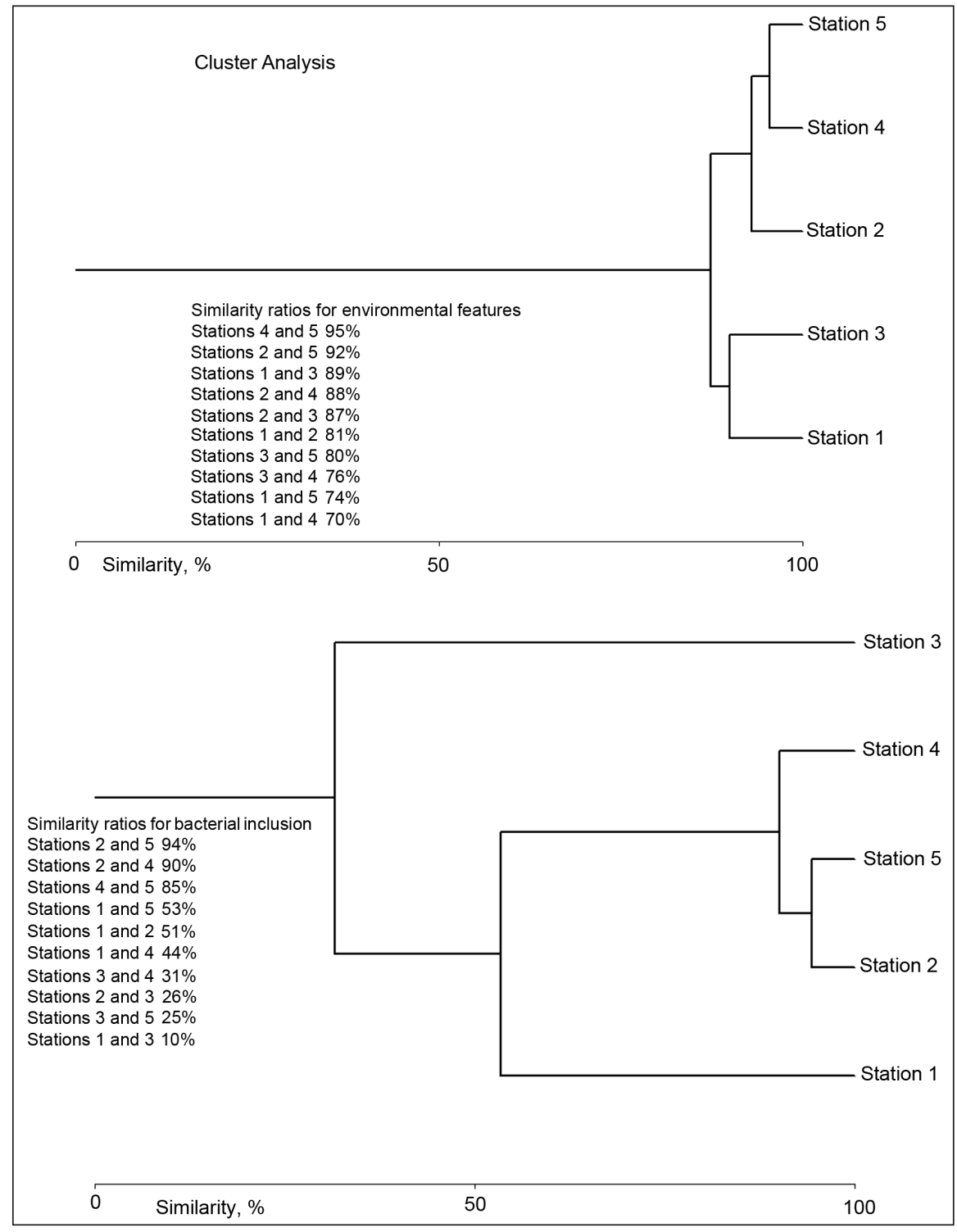

Fig. 4. Results of cluster analysis for bacterial distribution including the environmental features at the sampling stations

component analysis and correspondence analysis (Figs. 5, 6).

E. coli bacteria was found in all sampling stations, which indicates bacterial contamination from settlements. It is known that this bacteria lives in the digestive system of humans and warm-blooded animals. Therefore, the findings of $E$. coli bacteria in the study confirms bacterial contamination of the river.

Furthermore, it was observed that the numbers of TCB and FCB in some sampling stations decrease due to low oxygen values. In this study, it was observed that the water temperature ranged between $4.5^{\circ} \mathrm{C}$ and $22^{\circ} \mathrm{C}$, $\mathrm{pH}$ values ranged between 7.4 and 8.4 , conductivity ranged between $172 \mu \mathrm{S} / \mathrm{cm}$ and $798 \mu \mathrm{S} / \mathrm{cm}$, dissolved oxygen ranged between 1.9 and $11 \mathrm{mg} / \mathrm{L}$, total hardness ranged between $9.8^{\circ} \mathrm{Fr}$ and $29^{\circ} \mathrm{Fr}$, phosphate values ranged between 0.05 and $0.8 \mathrm{mg} / \mathrm{L}$, and nitrate nitrogen values ranged between 2.5 and $90 \mathrm{mg} / \mathrm{L}$ (Table 1,2). No nitrite nitrogen was found at the sampling stations.

Physicochemical features like temperature, $\mathrm{pH}$, conductivity, dissolved oxygen, nutrients, and light can affect bacterial distribution in water resources. Temperature is a very important feature which affected the distribution and growth of bacteria in water ecosystems (Arda, 2000). Also, temperature affects a lot of physicochemical reactions in water. Metabolic activities in microorganisms are related with $\mathrm{pH}$ values (Koru, Cirik, 2003). Keeton et al. (2003) reported that bacteria 


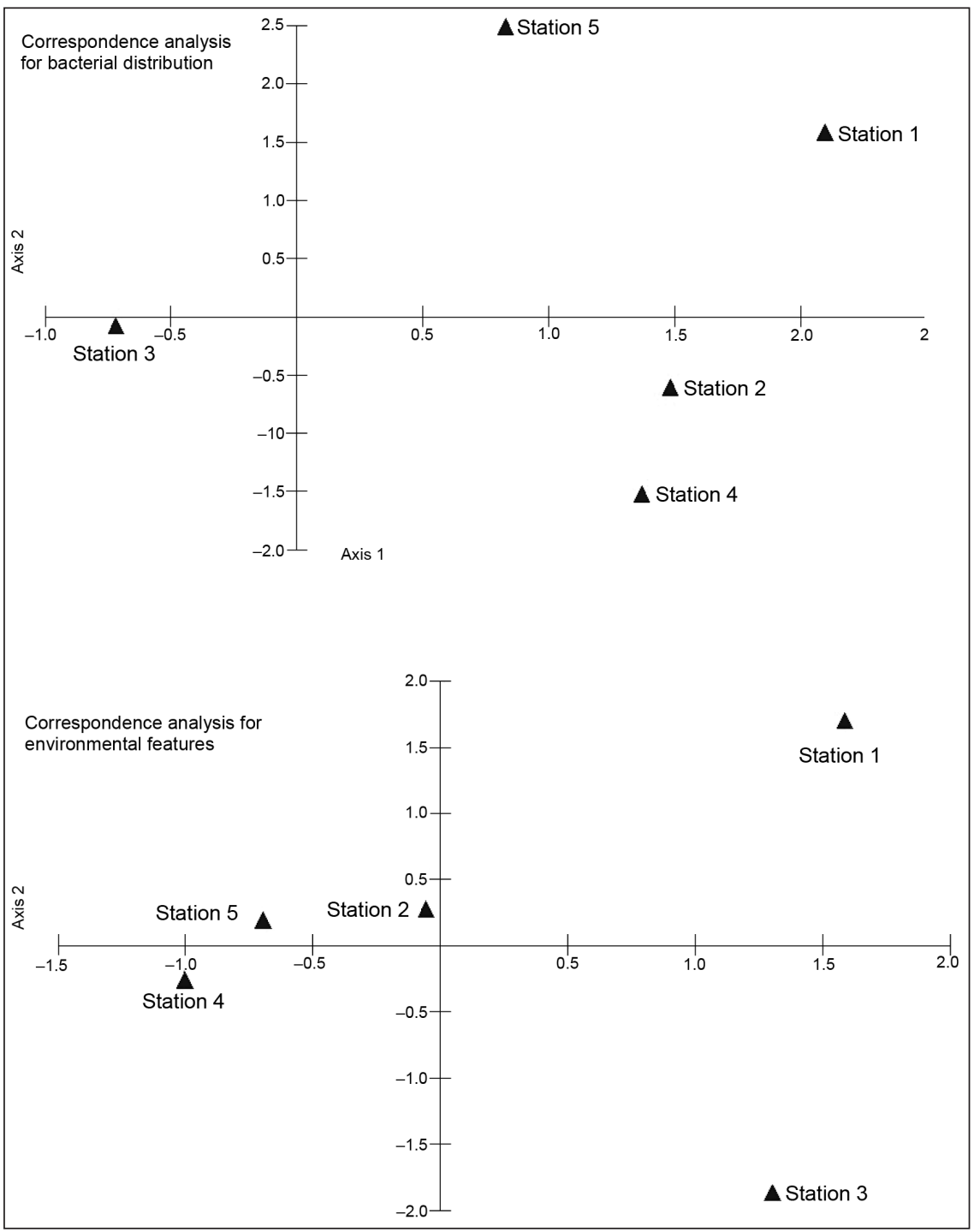

Fig. 5. Results of correspondence analysis for bacterial distribution and environmental features at the sampling stations

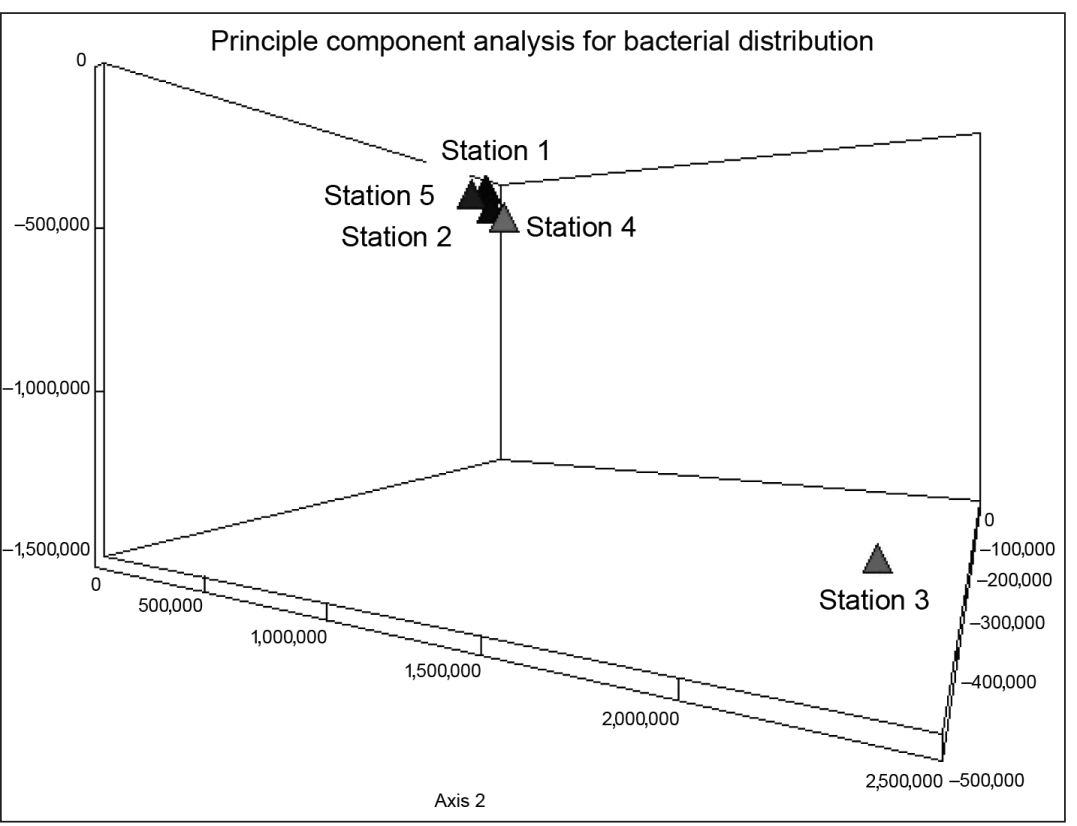

Fig. 6. Results of principle component analysis for bacterial distribution at the sampling stations 
Table 1. The average values of physicochemical properties at the sampling stations

\begin{tabular}{ccccccccc}
\hline STATIONS $\rightarrow$ Parameters & Station 1 & Station 2 & Station 3 & Station 4 & Station 5 & Average \\
\hline${ }^{*} \mathrm{WT}\left({ }^{\circ} \mathrm{C}\right)$ & 11 & 11 & 11 & 11 & 11 & 11 \\
\hline${ }^{*} \mathrm{EC}(\mu \mathrm{S} / \mathrm{cm})$ & 249 & 405 & 315 & 523 & 475 & 393 \\
\hline $\mathrm{pH}$ & 7.9 & 8.0 & 7.8 & 8.0 & 8.1 & 7.9 \\
\hline${ }^{*} \mathrm{DO}(\mathrm{mg} / \mathrm{L})$ & 5.5 & 5.7 & 5.2 & 5.4 & 5.6 & 5.48 \\
\hline${ }^{*} \mathrm{TH}\left({ }^{\circ} \mathrm{Fr}\right)$ & 18 & 20 & 16 & 25 & 22 & 20.2 \\
\hline $\mathrm{Ca}(\mathrm{mg} / \mathrm{L})$ & 54.6 & 58.31 & 54.5 & 53.17 & 56.25 & 55.36 \\
\hline $\mathrm{Mg}(\mathrm{mg} / \mathrm{L})$ & 13.23 & 16.75 & 13.81 & 24.05 & 19.11 & 17.39 \\
\hline $\mathrm{o}-\mathrm{PO}(\mathrm{mg} / \mathrm{L})$ & 0.526 & 0.344 & 0.447 & 0.231 & 0.265 & 0.362 \\
\hline $\mathrm{NO}_{3}-\mathrm{N}(\mathrm{mg} / \mathrm{L})$ & 20.72 & 31.78 & 8.86 & 42.06 & 40.46 & 28.76 \\
\hline
\end{tabular}

* (WT - water temperature; EC - conductivity; DO - dissolved oxygen; TH - total hardness)

Table 2. The average values of physicochemical parameters at monthly intervals

\begin{tabular}{c|c|c|c|c|c|c}
\hline Months $\rightarrow$ Parameters & December & January & February & March & April & May \\
\hline${ }^{*} \mathrm{WT}\left({ }^{\circ} \mathrm{C}\right)$ & 5.3 & 5.3 & 6.8 & 7.1 & 18.1 & 22.2 \\
\hline${ }^{*} \mathrm{EC}(\mu \mathrm{S} / \mathrm{cm})$ & 395 & 288 & 365 & 290 & 471 & 591 \\
\hline $\mathrm{pH}$ & 7.8 & 8.5 & 8.2 & 7.7 & 7.6 & 7.9 \\
\hline${ }^{*} \mathrm{DO}(\mathrm{mg} / \mathrm{L})$ & 6.5 & 9.2 & 4.8 & 2.3 & 2.1 & 8.4 \\
\hline${ }^{*} \mathrm{TH}\left({ }^{\circ} \mathrm{Fr}\right)$ & 20 & 29 & 18 & 15 & 20 & 18 \\
\hline $\mathrm{Ca}(\mathrm{mg} / \mathrm{L})$ & 60.1 & 74.9 & 52.8 & 50.5 & 55.3 & 49.9 \\
\hline $\mathrm{Mg}(\mathrm{mg} / \mathrm{L})$ & 11.1 & 25.4 & 15.1 & 10.8 & 16.9 & 16.3 \\
\hline $\mathrm{o}-\mathrm{PO}(\mathrm{mg} / \mathrm{L})$ & 0.09 & 0.23 & 0.47 & 0.69 & 0.34 & 0.33 \\
\hline $\mathrm{NO}_{3}-\mathrm{N}(\mathrm{mg} / \mathrm{L})$ & 73.1 & 7.17 & 17.9 & 33.8 & 16.8 & 23.6 \\
\hline
\end{tabular}

* (WT - water temperature; EC - conductivity; DO - dissolved oxygen; TH - total hardness)

have maximum growth at $\mathrm{pH}$ values in the range of 6.5 to 7.5. Dissolved oxygen and conductivity are very important parameters in determining biological distribution in the water.

According to Spearman correlation index, this study found that bacterial distribution had a positive correlation with conductivity, but it had a negative correlation with total hardness. Also, it was determined that the numbers of TCB at station 1 were correlated with magnesium $(r=+0.88, p<0.05)$ and phosphate $(r=-0.82$, $p<0.05)$; the numbers of TCB at station 3 were correlated with conductivity $(r=+0.94, p<0.05)$ and $\mathrm{pH}(r=-0.82, \mathrm{p}<0.05)$; the numbers of TCB at station 4 were correlated with $\mathrm{pH}(r=+0.81$, $p<0.05)$, dissolved oxygen $(r=+0.88, p<0.05)$; the numbers of TMAB at station 5 were correlated with $\mathrm{pH}$ and dissolved oxygen $(r=+0.82$, $p<0.05)$. No statistical significance was found between the other measured parameters and numbers of bacteria $(p>0.05)$.

Although it was reported in previous studies that seasonal changes in temperature had correlations with the distribution of bacterial counts in aquatic environments (Swiatecki, 1997; Altinoluk-Mimiroglu, Camur-Elipek, 2017), the relation between bacterial counts and temperature was not found statistically meaningful. This situation can be explained by allochthonous bacteria in the river. When low temperature values were measured in the river, the number of bacteria could increase due to waste waters from the city.

Similar to the findings of our study, the conductivity and phosphate have positive correlations with heterotrophic bacteria counts in a previous study by Altinoluk-Mimiroglu and Camur-Elipek (2017). 
According to the results of multivariate analysis, it was found that stations 2 and 5 were the most similar to each other (with the similarity rate of $94 \%$ for cluster analysis) and stations 1 and 3 were the most different (the similarity rate of $10 \%$ ) with regard to the existing bacteria (Fig. 1). Although it was found that stations 1 and 3 had the highest similarity rate according to the environmental parameters, these stations differed the most regarding bacterial distribution. Such a situation can be explained by external bacteria loaded to the river.

Bacteriological findings in this study emphasize that polluted material that enters to the River has to be controlled. particular, anthropogenic activities related to aquatic ecosystems affect the bacteria and these activities do not permit to autochthonic effects of environmental factors. In this study it was also observed that bacteria at station 3 consisted of wastewater system that enters the river without control (Fig. 4). Consequently, an increase in FCB leads a limited water usage, it should be emergency prevents for the River. Erosional material from the flooded river can transport bacteria and nutrients into the river. Therefore, to provide sustainable usage of the River, uncontrolled discharges and overloaded can be prevented immediately.

\section{ACKNOWLEDGEMENTS}

Some data was provided from the TUBAP 2011/48 Project which supported by Trakya University Research Fund.

Received 27 February 2017 Accepted 2 May 2017

\section{References}

1. Altinoluk-Mimiroglu P, Camur-Elipek B. Bacterial composition inhabiting water column and bottom sediment in two different running water ecosystems of Meric-Ergene River Basin (Turkish Thrace). Fresenius Environmental Bulletin. 2017; 26(1a): 717-25.
2. Aqso A, Ozkul K, Karakaya H. An investigation on the bacterial contents of natural springs in a rural area of the middle Black Sea region in Turkey. Applied Ecology and Environmental Sciences. 2014; 2(5): 123-9.

3. Su kirliligi kontrolu yonetmeligi: SKKY [Water pollution control regulation]. Resmi Gazete: 31/12/2004; 25687. Turkish.

4. Arda M. Temel mikrobiyoloji [Basic microbiology]. Medisan Yayinevi, Ankara/Turkey: 2000; 1-490. Turkish.

5. Boyacioglu H. Surface water quality assessment using factor analysis. Water SA. 2006; 32(3): 389-93.

6. Egemen O, Sunlu U. Su kalitesi [Water quality]. Ege Universitesi Su Urunleri Fakultesi Yayinlari, II. Baski, Izmir: 1999; 1-148. Turkish.

7. Filik-Iscen C, Emiroglu O, Ilhan S, Arslan N, Yilmaz V, Ahiska S. Application of multivariate statistical techniques in the assessment of surface water quality in Uluabat Lake, Turkey. Environmental Monitoring and Assessment. 2008; 144(1-3): 269-76.

8. Halkman K. Gida mikrobiyolojisi uygulamalari [Applications on food microbiology]. Ankara: Basak Matbaacilik Ltd. Sti: 2005. Turkish.

9. Keeton WT, Gould JL, Gould CG. Genel Biyoloji. Palme yayincilik (Translated to Turkish by Demirsoy A, Türkan I, Gunduz E): 2003; $1-583$.

10. Kenar B, Altindis M. Hygenic quality investigation of both drinking and tap-waters in Afyon. The Medical Journal of Kocatepe. 2001; 2: $269-74$.

11. Koru E, Cirik S. The effects of temperature on growth and some biochemical characteristics of microalgae Spirulina platensis (Cyanophyceae). Ege University Journal of Fisheries and Aquatic Sciences. 2003; 20(3-4): 419-22.

12. Krebs CJ. Ecological Methodology. Addison Wesley Longman, Inc., Menlo Park California: 1999; 1-620.

13. Kuppusamy MR, Giridhar VV. Factor analysis of water quality characteristics including trace metal speciation in the coastal environmental 
system of Chennai Ennore. Environmental International. 2006; 32: 174-9.

14. Lindstrom ES, Kamst-Van Agterveld MP, Zwart G. Distribution of typical freshwater bacterial groups is associated with $\mathrm{pH}$, temperature, and lake water retention time. Applied and Environmental Microbiology. 2005; 71(12): 8201-6.

15. Olsen RL, Chappell RW, Loftis JC. Water quality sample collection, data treatment and results presentation for principal components analysis - literature review and Illinois River Watershed case study. Water Research. 2012; 46(9): 3110-22.

16. Shrestha S, Kazama F. Assesment of surface water quality using multivariate stataistical techniques: A case study of the Fuji river basin, Japan. Environmental Modelling \& Software. 2007; 22: 464-75.

17. Simeonov V, Stratis JA, Samara C, Zachariadis G, Voutsa D, Anthemidis A, Sofoniou M, Kouimtzis T. Assessment of the surface water quality in Northern Greece. Water Research. 2003; 37(17): 4119-24.

18. Singh KP, Malik A, Mohan D, Sinha S. Multivariate statistical techniques for the evaluation of spatial and temporal variations in water quality of Gomti River (India) - a case study. Water Research. 2004; 38(18): 3980-92.

19. Singh KP, Malik A, Sinha S. Water quality assessment and apportionment of pollution sources of Gomti river (India) using multivariate statistical techniques-a case study. Analytica Chimica Acta. 2005; 538(1-2): 355-74.

20. Swiatecki A. The use of bacteriological indicators in assessing the quality of surface waters. Teacher Training College, Olsztyn, Poland. 1997.

21. Zhang Y, Guo F, Meng W, Wang XQ. Water quality assessment and source identification of Daliao River Basin using multivariate statistical methods. Environmental Monitoring and Assessment. 2009; 152(1-4): 105-21.
Gonul Bulbul, Belgin Camur-Elipek

\section{BUITINIŲ ATLIEKŲ POVEIKIS VANDENS BAKTERIJŲ PASISKIRSTYMUI MERICOS UPĖJE (EDIRNE், TURKIJA)}

\section{Santrauka}

Gyventojų skaičiaus didejjimas, pramoniniai pokyčiai ir žemès ūkio veikla sukelia taršą vandens ekosistemose. Augant gero vandens paklausai, būtina stebèti gèlo vandens telkinius. Siekiant užtikrinti jų tvarų naudojimą, labai svarbu žinoti esamas biologines ir fizines-chemines vandens išteklių savybes. Šio tyrimo metu buvo tiriamas buitinių atliekų poveikis vandens bakterijų pasiskirstymui Mericos upejje, esančioje Edirnès miesto centre (Turkija): buvo paimti bakteriniai mėginiai, matuojamos fizinès-cheminès vandens savybès. Spearmano koreliacijos indeksu buvo vertinamas santykis tarp bakterijų pasiskirstymo ir aplinkos savybių. Nustatyta, kad bakterijų pasiskirstymas yra susijęs su kai kuriais aplinkos kintamaisiais, tačiau gyvenviečių nuotekos sukelia bakterinę taršą. Bakteriniai ir fiziniai-cheminiai duomenys buvo sugrupuoti naudojant kai kurias daugialypès analizès metodikas (klasterių analizę, pagrindinių komponentų ir atitikties analizę). Gauti rezultatai padèjo suskirstyti mėginių èmimo vietas pagal bakterines ir fizines-chemines savybes.

Raktažodžiai: buitinès atliekos, aplinkos ypatybès, vandens kokybé 